\title{
Feed value of Gliricidia fodder salt for sheep
}

\section{Valor alimentício do sal forrageiro de gliricídia para ovinos}

\author{
Luís Gabriel Alves Cirne ${ }^{1 *}$; Marly Rosa Baroni; \\ Gabriel Jorge Carneiro de Oliveira ${ }^{3}$; Soraya Maria Palma Luz Jaeger ${ }^{3}$; \\ Adriana Regina Bagaldo ${ }^{3}$; Paulo Andrade de Oliveira; \\ Ronaldo Lopes Oliveira ${ }^{5}$; Carlos Alberto da Silva Lêdo ${ }^{6}$; \\ José Carlos Barbosa ${ }^{7}$; Gleidson Giordano Pinto de Carvalho ${ }^{5}$
}

\begin{abstract}
This experiment aimed to evaluate the effect of supplementation with Gliricidia fodder salt on intake, nutrient digestibility, and feeding behavior of lambs. Twenty-five Santa Inês crossbred male sheep at approximately 180 days of age, with an average live weight of $25 \mathrm{~kg}$, were confined in individual $1-\mathrm{m}^{2}$ stalls and distributed in a randomized complete design with five treatments and five replications. Treatments consisted of $0\left(1,000 \mathrm{~g} / \mathrm{kg}^{-1} \mathrm{NaCl}\right), 930,950,970$, and $990 \mathrm{~g} / \mathrm{kg}^{-1}$ inclusion of Gliricidia hay (70, 50, 30, and $10 \mathrm{~g} / \mathrm{kg}^{-1} \mathrm{NaCl}$ in the formulation of the fodder salt, respectively). The animals were fed ground Tifton-85 (Cynodon spp.) hay, ground fodder salt and or mineral salt, and water ad libitum, at $07 \mathrm{~h} 00$ and $17 \mathrm{~h} 00$. Intakes of dry matter, mineral matter, organic matter, crude protein, ether extract, and neutral detergent fiber were influenced $(\mathrm{P}<0.05)$ by supplementation with Gliricidia fodder salt. Crude protein intake increased linearly $(\mathrm{P}<0.01)$, while mineral-salt intake decreased linearly $(\mathrm{P}<0.01)$ as the levels of Gliricidia hay in the fodder salt were increased. There was no difference $(\mathrm{P}>0.05)$ in nutrient digestibility due to supplementation. Rumination time and number of cuds ruminated per day decreased $(\mathrm{P}<0.05)$, whereas rumination chews per cud increased $(\mathrm{P}<0.05)$. Feed and rumination efficiencies $\left(\mathrm{g} \mathrm{DM}\right.$ and $\left.\mathrm{NDF} \mathrm{h}^{-1}\right)$ increased $(\mathrm{P}<0.01)$ with supplementation, and so did the rumination efficiency $(\mathrm{P}<0.01)$ expressed in $\mathrm{g}$ DM and NDF $\mathrm{cud}^{-1}$. Supplementation with Gliricidia fodder salt increases nutrient intake and positively changes the feeding behavior of lambs.
\end{abstract}

Key words: Alternative feed. Digestibility. Ethology. Intake. Supplementation.

\section{Resumo}

O experimento foi conduzido com o objetivo de avaliar o efeito da suplementação com sal forrageiro de gliricídia sobre o consumo, a digestibilidade dos nutrientes e o comportamento ingestivo em cordeiros. Foram utilizados 25 ovinos, machos, mestiços da raça Santa Inês, com aproximadamente 180 dias de

${ }^{1}$ Prof. e Pesquisador, Universidade Federal de Roraima, UFRR, Boa Vista, RR, Brasil. E-mail: lgabrielcirne@hotmail.com

2 Discente do curso de Mestrado em Ciência animal, Universidade Federal do Recôncavo da Bahia, UFRB, Cruz das Almas, BA, Brasil. E-mail: marlyrosa1@hotmail.com

3 Profs. e Pesquisadores, Universidade Federal do Recôncavo da Bahia, UFRB, Cruz das Almas, BA, Brasil. E-mail: gajocaol@, yahoo.com.br; soraluz@yahoo.com.br; arbagaldo@gmail.com

${ }^{4}$ Discente do Curso de Doutorado em Zootecnia, Universidade Estadual do Sudoeste da Bahia, UESB, Itapetinga, BA, Brasil. E-mail: pazootecnista@gmail.com

5 Profs. e Pesquisadores, Universidade Federal da Bahia, UFBA, Salvador, BA, Brasil. E-mail: ronaldozootecnista@gmail.com; gleidsongiordano@yahoo.com.br

6 Pesquisador, Empresa Brasileira de Pesquisa Agropecuária, EMBRAPA, Cruz das Almas, BA, Brasil. E-mail: ledo@cnpmf.embrapa.br

${ }^{7}$ Prof. e Pesquisador, Universidade Estadual Paulista, UNESP, Jaboticabal, SP, Brasil. E-mail: jcbarbosa@fcav.unesp.br

* Author for correspondence 
idade, peso vivo médio de $25 \mathrm{~kg}$, confinados em baias individuais de $1 \mathrm{~m}^{2}$, distribuídos num delineamento experimental inteiramente casualizado, com cinco tratamentos e cinco repetições, em que os tratamentos foram constituídos de 0 ( $\left.1000 \mathrm{~g} / \mathrm{kg}^{-1} \mathrm{de} \mathrm{NaCl}\right), 930,950,970$ e $990 \mathrm{~g} / \mathrm{kg}^{-1}$ de inclusão de feno de gliricidia $\left(70,50,30\right.$ e $10 \mathrm{~g} / \mathrm{kg}^{-1}$ de NaCl na formulação do sal forrageiro, respectivamente). Os animais foram alimentados com feno de Tifton-85 (Cynodon spp.) triturado, sal forrageiro moído e/ou mineral e água $\mathrm{ad}$ libitum, às $7 \mathrm{~h} 00$ e às $17 \mathrm{~h} 00$. O consumo de matéria seca, sal mineral, matéria orgânica, proteína bruta, extrato etéreo e fibra em detergente neutro foram influenciados $(\mathrm{P}<0,05)$ pela suplementação com sal forrageiro de gliricidia. Houve efeito linear crescente $(\mathrm{P}<0,01)$ para o consumo de proteína bruta e decrescente $(\mathrm{P}<0,01)$ para o consumo de sal mineral em função dos níveis de inclusão de feno de gliricidia no sal forrageiro. Não houve diferença $(\mathrm{P}>0,05)$ na digestibilidade dos nutrientes em função da suplementação. $\mathrm{O}$ tempo de ruminação e o número de bolos ruminados por dia reduziram $(\mathrm{P}<0,05)$, enquanto que as mastigações merícicas por bolo aumentaram $(\mathrm{P}<0,05)$. As eficiências de alimentação e ruminação (g MS e FDN hora1) foram incrementadas $(\mathrm{P}<0,01)$ pela suplementação, assim como a eficiência de ruminação $(\mathrm{P}<0,01)$, expressa em $\mathrm{g}$ de $\mathrm{MS}$ e FDN bolo ${ }^{-1}$. A suplementação com sal forrageiro de gliricidia aumenta o consumo de nutrientes e altera positivamente o comportamento ingestivo de cordeiros.

Palavras-chave: Alimento alternativo. Consumo. Digestibilidade. Etologia. Suplementação.

\section{Introduction}

The sheep species is characterized by its ability to adapt to the more diversified environmental conditions, occurring in practically all regions of the world. The Brazilian semi-arid biome comprises $70 \%$ of the Northeast area, where shallow, lowfertility soils characterized by the Caatinga vegetation predominate (COSTA et al., 2011). The most common rearing system in this region is the extensive type, in which the animal itself harvests the feed directly in the field, thereby reducing costs with herbage collection and facilities to supply the collected material. The pasture is the main feed for herds in this biome.

The environmental limitations in the semiarid environment are clearly visible in ruminant production, which is affected directly by the irregular distribution of rains over the year, leading to low herbage allowance during the dry season. Thus, because the rearing system in the semi-arid region is manly the extensive type, having the native pasture as the source of roughage feed, the herbage availability is directly impaired by the irregular rainfall. Therefore, the occurrence of long scarcity periods compromises the production of herbage with good nutritive value throughout the year, always causing the herd to go through a feed restriction period (COSTA et al., 2011).
The use of alternative feedstuffs in ruminant production has grown in the last few years as a result of the need for developing diets at lower costs, aiming at good animal performance. One example is the fodder salt, defined as a mixture of mineral salt with ground hay made from some eudicotyledons, which is a potential low-cost technology for application in small-ruminant production systems, especially those managed on pasture (OLIVEIRA et al., 2010). The use of fodder salt from Leucaena, cassava shoots, and Gliricidia, in sheep diets, provides better performance to supplemented animals (STRADA et al., 2006; GONÇALVES et al., 2008; CIRNE et al., 2012).

Gliricidia sepium is a fast-growing, mediumsized legume tree native to Mexico, Central America, and Northern South America whose deep rooting provides it with a remarkable tolerance to droughts. It is considered a multipurpose species: for herbage, reforestation, green manure, hedging, among others. It is indicated as herbage for cattle, sheep, and goat for the high protein content in its leaves that ranges from 20 to $30 \%$ of crude protein (CARVALHO FILHO et al., 1997).

Knowledge of the feeding behavior is a tool of greatimportance in the evaluation of diets, as itallows the producer to adjust the feeding management of animals to obtain better productive performance. According to Hodgson (1990), ruminants adapt to 
the many feeding, management, and environmental conditions, modifying their feeding-behavior parameters to achieve and maintain a certain level of intake compatible with its nutritional requirements.

In this scenario, this study aimed to determine the best level of inclusion of $\mathrm{NaCl}$ in the composition of Gliricidia fodder salt.

\section{Materials and Methods}

The study was carried out in the Sheep Farming section of the Experimental Farm of the Center for Agricultural, Environmental, and Biological Sciences at the Federal University of Recôncavo da Bahia (UFRB). The experiment began on 09/02/2010 and ended on 24/02/2010, comprising 15 days for adaptation to stalls and diets and five days for collection, totaling 20 days. Twenty-five mixed-breed (different genetic combinations with Santa Inês breed) male lambs at approximately 180 days of age, with an average initial weight of $25.81 \pm 1.91 \mathrm{~kg}$, were kept in individual $1-\mathrm{m}^{2}$ stalls equipped with feeders, salt troughs, and drinkers.

Lambs were fed ground Tifton-85 grass (Cynodon spp.) hay (TGH), water, and mineral salt and/or ground Gliricidia fodder salt ad libitum. Tifton hay, mineral salt, and/or fodder salt refusals were gathered, weighed, and subtracted from the total supplied aiming to quantify the feed intake by the animals, individually. The diet was supplied at $07 \mathrm{~h} 00$ and $17 \mathrm{~h} 00$, allowing at least $10 \%$ as refusals.

The characteristics evaluated in this study were the intakes of dry matter (DM), Gliricidia fodder salt (GFS), Tifton-85 grass hay (TGH), mineral salt (MS), organic matter (OM), crude protein (CP), ether extract (EE), and neutral detergent fiber (NDF); the digestibility of nutrients; and the feeding behavior of lambs.

The Gliricidia was obtained from the Experimental Farm of UFRB, in an area with low-fertility soil. The material consisted of tender branches with leaves from the arboreal stratum, at around 120 days of age, in the vegetative stage, which were previously dried in the sun for two days, and turned every $4 \mathrm{~h}$ until it reached hay point, with $150 \mathrm{~g} / \mathrm{kg}^{-1}$ moisture (CAVALCANTE et al., 2004). After haying, the material was ground through a sieve with $0.8 \mathrm{~mm}$ screen aiming to facilitate the uniformity with the mineral salt and prevent selectivity by the animals.

The chemical composition of the feedstuffs used in the experimental diets, as well as of the treatments, was analyzed at the Laboratory of Forage Crops at Southwest Bahia State University (Table 1).

Table 1. Concentrations of dry matter (DM), organic matter (OM), crude protein (CP), ether extract (EE), ash, neutral detergent fiber (NDF), acid detergent fiber (ADF), and lignin in experimental diets.

\begin{tabular}{lccccccc}
\hline \multirow{2}{*}{ Item } & \multirow{2}{*}{ Tifton 85 hay } & \multirow{2}{*}{ Gliricidia hay } & \multirow{2}{*}{ Mineral salt } & \multicolumn{5}{c}{ Gliricidia level $\left(\mathrm{g} / \mathrm{kg}^{-1}\right)$} \\
\cline { 5 - 7 } & & & & 930 & 950 & 970 & 990 \\
\hline $\mathrm{DM}^{1}$ & 903.0 & 930.0 & 991.0 & 895.0 & 900.0 & 910.0 & 914.0 \\
$\mathrm{OM}^{1}$ & 836.0 & 857.9 & - & 643.0 & 675.0 & 740.0 & 809.0 \\
$\mathrm{CP}^{1}$ & 56.0 & 211.0 & - & 220.0 & 229.0 & 240.0 & 256.0 \\
$\mathrm{EE}^{1}$ & 26.0 & 28.2 & - & 51.0 & 57.0 & 57.0 & 60.0 \\
$\mathrm{Ash}^{1}$ & 67.0 & 72.1 & - & 252.0 & 225.0 & 170.0 & 105.0 \\
$\mathrm{NDF}^{1}$ & 855.0 & 347.3 & - & 599.0 & 623.0 & 625.0 & 629.0 \\
$\mathrm{ADF}^{1}$ & 692.0 & 258.3 & - & 490.0 & 500.0 & 517.0 & 568.0 \\
Lignin $^{1}$ & 111.0 & 86.0 & - & 134.0 & 159.0 & 174.0 & 235.0 \\
\hline
\end{tabular}

${ }^{1}$ in $\mathrm{g} \mathrm{kg}^{-1}$ dry matter. 
From the 12th to the 14th day of the experimental period, total feces collection was performed using collection bags. Twenty-four hours after each collection day, feces were harvested, weighed, and sampled (200 g/kg of the total excreted), forming a composite sample of each animal at the end of the period. During the feedlot period, samples of feed supplied, refusals, and feces were collected and pre-dried in a forced-air oven at $65^{\circ} \mathrm{C}$ for $72 \mathrm{~h}$ and later ground in a Wiley mill with 1-mm sieves for the chemical determinations of dry matter (DM), organic matter $(\mathrm{OM})$, crude protein $(\mathrm{CP})$, ether extract (EE), and ash, according to the methodology described by Silva and Queiroz (2002). Cell wall components, neutral detergent fiber corrected for ash and protein (NDFap), acid detergent fiber (ADF), and acid detergent lignin (ADL) were determined following Van Soest (1994).

Nutrient intake was calculated as the difference between the amount of the nutrient present in the feeds supplied and the amount of that nutrient in the refusals. Nutrient digestibility was determined according to the following equation: digestibility $(\%)=[$ nutrient ingested $(\mathrm{g})-$ nutrient $=$ excreted in feces $(\mathrm{g}) /$ nutrient ingested $(\mathrm{g})]^{*} 100$, according to Moreno et al. (2010).

On the 9th day, the feeding behavior was evaluated based on an individual visual observation of all animals, made by trained observers in a relay system who were positioned strategically so as not to disturb the animals, for $24 \mathrm{~h}$, with 5-min intervals. Observers recorded the time spent feeding, ruminating, and idle. On the same day, the number of rumination chews (NRC, $\mathrm{n} \mathrm{cud}^{-1}$ ) and the time taken to ruminate each cud (TRC, s cud ${ }^{-1}$ ) were counted using a digital stopwatch.

To obtain the average number of chews and time, three rumen cuds were observed in three periods of the day $(10 \mathrm{~h} 00-12 \mathrm{~h} 00,14 \mathrm{~h} 00-16 \mathrm{~h} 00$, and 18h00-20h00). The time and number of chews were calculated for each rumen cud per animal. To determine the number of daily cuds, the total rumination time was divided by the average time spent on the rumination of each cud, described previously. The feed and rumination efficiencies, expressed in $\mathrm{g} \mathrm{DM} \mathrm{h}^{-1}$ and $\mathrm{g} \mathrm{NDF} \mathrm{h}{ }^{-1}$, were obtained by dividing the average daily intake of DM and NDF by the total time spent feeding and/or ruminating over $24 \mathrm{~h}$, respectively. These and other variables obtained in this experiment, such as the total chewing time (TCT), number of cuds ruminated per day (CRD), and number of rumination chews per day (RCD, $\mathrm{n} \mathrm{d}^{-1}$ ), were obtained as described by Polli et al. (1996) and Bürger et al. (2000). During data collection, in the night-time observation of the animals, the environment was maintained under artificial illumination.

The experimental design was completely randomized (RCD), with five treatments and five replications, totaling 25 experimental units. Treatments (Table 2) consisted of zero $(1,000 \mathrm{~g} /$ $\mathrm{kg} \mathrm{NaCl}$ ), 930, 950, 970, and $990 \mathrm{~g} / \mathrm{kg}$ inclusion of Gliricidia hay $(70,50,30$, and $10 \mathrm{~g} / \mathrm{kg} \mathrm{NaCl}$ in the formulation of the fodder salt, respectively). Data were studied by analysis of variance and decomposed into four orthogonal contrasts: 1 . Control vs. fodder salt comparison; 2. Linear effect of hay level in the salt; 3. Quadratic effect of hay level in the salt; and 4. Cubic effect of hay level in the salt, using the AgroEstat statistical program (BARBOSA; MALDONADO, 2013), adopting 1\% or $5 \%$ significance levels.

Table 2. Ingredients utilized in the preparation of the Gliricidia fodder salt $\left(\mathrm{g} / \mathrm{kg}^{-1}\right)$.

\begin{tabular}{lcc}
\hline Fodder salt & Gliricidia hay & $\mathrm{NaCl}^{*}$ \\
\hline $100 \% \mathrm{NaCl}$ & - & $1,000.00$ \\
$93 \%$ Gliricidia hay & 930.00 & 70.00 \\
$95 \%$ Gliricidia hay & 950.00 & 50.00 \\
$97 \%$ Gliricidia hay & 970.00 & 30.00 \\
$99 \%$ Gliricidia hay & 990.00 & 10.00 \\
\hline
\end{tabular}

*Provides per kilogram of product: calcium (Max) $174 \mathrm{~g}$, chlorine $178 \mathrm{~g}$, cobalt $150 \mathrm{mg}$, copper $300 \mathrm{mg}$, sulfur $6.2 \mathrm{~g}$, iron 4,000 mg, phosphorus $100 \mathrm{~g}$, iodine $110 \mathrm{mg}$, magnesium $6 \mathrm{~g}$, manganese $1,400 \mathrm{mg}$, selenium $20 \mathrm{mg}$, sodium $117 \mathrm{~g}$ and zinc $3,750 \mathrm{mg}$. 


\section{Results and Discussion}

Dry matter $(\mathrm{DM})$ intake was influenced $(\mathrm{P}<0.05)$ by supplementation with GFS, but there was no difference between Gliricidia levels (Table 3). The highest DM intake (average $0.909 \mathrm{~kg} \mathrm{day}^{-1}$ ) by the animals that consumed GFS can be attributed to the intake of CP from Gliricidia, which contained 211 $\mathrm{g} / \mathrm{kg}^{-1} \mathrm{CP}$ (Table 2) in its chemical composition, which possibly strengthened the rumen bacteria due to the greater nitrogen uptake, consequently increasing the efficiency of ruminal activity, allowing a greater passage rate to the feed through the digestion process (S'THIAGO, 1999). This result corroborates those observed by Gonçalves et al. (2008), who evaluated the DM intake of feedlot Santa Inês mixed-breed sheep (different genetic combinations) supplemented with fodder salt from Leucaena and cassava shoots and observed a higher DM intake by supplemented animals.

Table 3. Voluntary intakes $\left(\mathrm{kg} \mathrm{day}^{-1}\right)$ of dry matter (DM), Gliricidia fodder salt (GFS), Tifton- 85 grass hay (TGH), and mineral salt (MS) by lambs supplemented with Gliricidia fodder salt.

\begin{tabular}{|c|c|c|c|c|c|c|c|c|c|c|}
\hline \multirow{2}{*}{ Item } & \multicolumn{5}{|c|}{ Gliricidia level $\left(\mathrm{g} / \mathrm{kg}^{-1}\right)$} & \multirow{2}{*}{$\begin{array}{c}\mathrm{NaCl} \\
\text { vs. } \mathrm{GFS}^{1}\end{array}$} & \multicolumn{3}{|c|}{ P-value } & \multirow{2}{*}{$\mathrm{CV}(\%$} \\
\hline & 0 & 930 & 950 & 970 & 990 & & $\mathrm{~L}$ & $\mathrm{Q}$ & $\mathrm{C}$ & \\
\hline $\mathrm{DM}$ & 0.710 & 0.842 & 0.934 & 0.881 & 0.980 & 0.016 & ns & ns & ns & 17.48 \\
\hline GFS & - & 0.094 & 0.104 & 0.113 & 0.162 & - & 0.021 & ns & ns & 44.63 \\
\hline TGH & 0.704 & 0.748 & 0.829 & 0.767 & 0.817 & 0.230 & ns & $\mathrm{ns}$ & ns & 44.63 \\
\hline MS & 0.005 & 0.018 & 0.015 & 0.010 & 0.005 & 0.019 & 0.005 & ns & ns & 47.51 \\
\hline \multicolumn{10}{|c|}{ Regression equation } & $\mathrm{r}^{2}$ \\
\hline GFS & \multicolumn{9}{|c|}{$Y=-901.48900+10.6290000 x$} & 0.16 \\
\hline MS & \multicolumn{9}{|c|}{$Y=219.589000-2.159000 x$} & 0.71 \\
\hline
\end{tabular}

${ }^{1} \mathrm{P}$-value for the orthogonal contrast between control and fodder salt; $\mathrm{L}=$ linear; $\mathrm{Q}=$ quadratic; $\mathrm{C}=$ cubic.

There was an increasing linear effect $(\mathrm{P}<0.05)$ for GFS intake as the levels of inclusion of Gliricidia were increased, with every $10 \mathrm{~g} / \mathrm{kg}^{-1}$ of inclusion in the fodder salt increasing total GFS intake by 0.010 $\mathrm{kg}$. The average GFS intake of $0.118 \mathrm{~kg}^{\text {day }}{ }^{-1}$ was similar to the $0.102 \mathrm{~kg} \mathrm{day}^{-1}$ found by Cirne et al. (2012), who evaluated the performance of feedlot Santa Inês mixed-breed lambs supplemented with GFS; and higher than the $0.066 \mathrm{~kg} \mathrm{day}^{-1}$ observed by Silva et al. (2006) in Santa Inês mixed-breed sheep supplemented with GFS. However, for animals supplemented with fodder salt from cassava shoots and Leucaena, Silva et al. (2006) and Gonçalves et al. (2008) observed average intakes of 0.483 and $0.739 \mathrm{~kg} \mathrm{day}^{-1}$, and 0.363 and $0.346 \mathrm{~kg} \mathrm{day}^{-1}$, respectively. These elevated intakes observed in the animals supplemented with fodder salt from cassava shoots and Leucaena probably stemmed from the high acceptability of these forages by the animals, and also from the inclusion of $50 \mathrm{~g} / \mathrm{kg}^{-1}$ corn meal in the mixture. As regards the intake of TGH, no influence of the levels of Gliricidia in the fodder salt or the treatment with $\mathrm{NaCl}$ alone was found.

Supplementation with GFS affected $(\mathrm{P}<0.05)$ the mineral-salt intake, which decreased linearly $(\mathrm{P}<0.01)$ as the levels of inclusion of Gliricidia in the fodder salt were increased; every $10 \mathrm{~g} /$ $\mathrm{kg}^{-1}$ increase in the inclusion level provided a $2 \mathrm{~g}$ reduction in total mineral-salt intake (Table 3). The lower mineral-salt intake by the animals receiving the treatment with $10 \mathrm{~g} / \mathrm{kg}^{-1} \mathrm{NaCl}$ in the fodder salt is possibly due to the lower amount of $\mathrm{NaCl}$ in the mixture, which led to the lowest intake by sheep, of $5 \mathrm{~g} \mathrm{day}^{-1}$. Araújo Filho et al. (2000) recommended approximately $10 \mathrm{~g}$ animal $\mathrm{day}^{-1}$ as mineral-salt 
intake by sheep, which, according to this study, can be achieved with inclusion of up to $970 \mathrm{~g} / \mathrm{kg}^{-1}$ Gliricidia in the formulation of GFS.

The intakes of $\mathrm{OM}\left(0.843 \mathrm{~kg}\right.$ day $\left.^{-1}\right), \mathrm{CP}$ $\left(0.079 \mathrm{~kg} \mathrm{day}^{-1}\right)$, EE $\left(0.035 \mathrm{~kg} \mathrm{day}^{-1}\right)$, and NDF $\left(0.761 \mathrm{~kg} \mathrm{day}^{-1}\right)$ were also influenced $(\mathrm{P}<0.05)$ by supplementation with GFS (Table 4). Crude protein intake increased linearly $(\mathrm{P}<0.01)$ as the levels of Gliricidia were increased (Table 4), with every $10 \mathrm{~g} / \mathrm{kg}^{-1}$ inclusion of Gliricidia in the fodder salt providing an increase of $0.004 \mathrm{~kg}$ day $^{-1}$ in this variable. The higher $\mathrm{CP}$ intake may be a result of the increased consumption of GFS by the animals as the amount of Gliricidia was increased. However, the difference observed for the intakes of OM and NDF by the animals supplemented with GFS in relation to those fed $\mathrm{NaCl}$ was likely due to the greater DM intake. A similar result was reported by Gonçalves et al. (2008), who evaluated the performance of lambs supplemented with fodder salt from Leucaena and cassava shoots and observed higher NDF intake by supplemented animals.

Table 4. Voluntary intakes $\left(\mathrm{kg} \mathrm{day}^{-1}\right)$ of organic matter $(\mathrm{OM})$, crude protein $(\mathrm{CP})$, ether extract $(\mathrm{EE})$, and neutral detergent fiber (NDF) by lambs supplemented with Gliricidia fodder salt.

\begin{tabular}{|c|c|c|c|c|c|c|c|c|c|c|}
\hline \multirow{2}{*}{ Item } & \multicolumn{5}{|c|}{ Gliricidia level $\left(\mathrm{g} / \mathrm{kg}^{-1}\right)$} & \multirow{2}{*}{$\begin{array}{c}\mathrm{NaCl} \\
\text { vs. GFS }\end{array}$} & \multicolumn{3}{|c|}{ P-value } & \multirow{2}{*}{$\mathrm{CV}(\%)$} \\
\hline & 0 & 930 & 950 & 970 & 990 & & $\mathrm{~L}$ & Q & $\mathrm{C}$ & \\
\hline $\mathrm{OM}$ & 0.657 & 0.780 & 0.851 & 0.829 & 0.912 & 0.013 & $\mathrm{~ns}$ & ns & ns & 17.07 \\
\hline $\mathrm{CP}$ & 0.044 & 0.069 & 0.073 & 0.081 & 0.093 & 0.001 & 0.004 & ns & ns & 17.47 \\
\hline $\mathrm{EE}$ & 0.026 & 0.035 & 0.035 & 0.032 & 0.038 & 0.004 & ns & ns & ns & 12.24 \\
\hline $\mathrm{NDF}$ & 0.617 & 0.706 & 0.787 & 0.741 & 0.811 & 0.033 & ns & ns & ns & 17.22 \\
\hline & \multicolumn{9}{|c|}{ Regression equation } & $\mathrm{r}^{2}$ \\
\hline $\mathrm{CP}$ & \multicolumn{9}{|c|}{$\mathrm{Y}=310.15900+4.05900000 \mathrm{x}$} & 0.24 \\
\hline
\end{tabular}

${ }^{1} \mathrm{P}$-value for the orthogonal contrast between control and fodder salt; $\mathrm{L}=$ linear; $\mathrm{Q}=$ quadratic; $\mathrm{C}=$ cubic.

The higher intakes of $\mathrm{CP}$ and EE observed in the present study in the group of lambs supplemented with GFS compared with those receiving only $\mathrm{NaCl}$ is attributed to the consumption of Gliricidia in the fodder salt, since this legume had a higher CP and EE content in its composition than TGH did (Table 1). This finding is similar to those observed by Cirne et al. (2012), who obtained higher CP and EE intake by animals supplemented with GFS; by Gonçalves et al. (2008), who observed greater CP intake in animals receiving supplementation based on fodder salt from Leucaena and cassava shoots; and by Silva et al. (2006), who recorded a higher CP intake for animals supplemented with fodder salt from Leucaena and cassava shoots.
The digestibility coefficients of DM $(513.20 \mathrm{~g} /$ $\left.\mathrm{kg}^{-1}\right), \mathrm{OM}\left(565.72 \mathrm{~g} / \mathrm{kg}^{-1}\right), \mathrm{CP}\left(538.60 \mathrm{~kg}^{-1}\right), \mathrm{EE}$ (821.96 $\left.\mathrm{g} / \mathrm{kg}^{-1}\right)$, and NDF (506.56 $\mathrm{g} / \mathrm{kg}^{-1}$ ) were not influenced $(\mathrm{P}>0.05)$ by the experimental diets (Table 5).

The increase in the levels of $\mathrm{NaCl}$ in the fodder salt led to a reduction in NDF and ADF contents in the tested diets, possibly due to the reduced amount of Gliricidia hay in the mixture. However, the lignin content of the Gliricidia fodder salt is higher when compared with that of TGH (Table 2). This elevation in the dietary fibrous fractions did not influence their digestibility, though. This was probably due to the low fodder-salt intake, to the point that digestibility was not affected. 
Table 5. Coefficients of digestibility (CD) of dry matter (DM), organic matter (OM), crude protein (CP), ether extract (EE), and neutral detergent fiber (NDF) of lambs supplemented with Gliricidia fodder salt.

\begin{tabular}{|c|c|c|c|c|c|c|c|c|c|c|}
\hline \multirow{2}{*}{$\mathrm{CD}$} & \multicolumn{5}{|c|}{ Gliricidia level $\left(\mathrm{g} / \mathrm{kg}^{-1}\right)$} & \multirow{2}{*}{$\begin{array}{c}\mathrm{NaCl} \\
\text { vs GFS }^{1}\end{array}$} & \multicolumn{3}{|c|}{ P-value } & \multirow{2}{*}{ CV $(\%)$} \\
\hline & 0 & 930 & 950 & 970 & 990 & & $\mathrm{~L}$ & Q & $\mathrm{C}$ & \\
\hline $\mathrm{DM}$ & 553.9 & 539.7 & 520.5 & 521.7 & 430.2 & 0.322 & ns & ns & ns & 17.31 \\
\hline $\mathrm{OM}$ & 578.8 & 582.6 & 573.8 & 587.6 & 505.8 & 0.712 & ns & ns & ns & 15.44 \\
\hline $\mathrm{CP}$ & 461.4 & 428.4 & 487.8 & 524.4 & 431.0 & 0.914 & ns & ns & ns & 25.63 \\
\hline $\mathrm{EE}$ & 822.6 & 800.0 & 841.0 & 794.8 & 851.4 & 0.987 & ns & ns & ns & 11.49 \\
\hline NDF & 517.2 & 531.2 & 524.4 & 532.2 & 427.8 & 0.789 & ns & ns & ns & 19.42 \\
\hline
\end{tabular}

${ }^{1} \mathrm{P}$-value for the orthogonal contrast between control and fodder salt; $\mathrm{L}=$ linear; $\mathrm{Q}=$ quadratic; $\mathrm{C}=$ cubic.

Supplementation with GFS reduced $(\mathrm{P}<0.05)$ the time spent by the animals on the rumination activity (Table 6), which can be explained by the lower residence time of the herbage in the rumen and reticulum, due to the higher efficiency of the ruminal activity. Nevertheless, supplementation did not influence $(\mathrm{P}>0.05)$ the times spent on the chewing and idle activities. The longer rumination time shown by the animals fed $\mathrm{NaCl}$ possibly offset the times spent feeding and idle. Nunes et al. (2010), however, evaluated the supplementation of lambs with sisal (Agave sisalana) fodder salt and did not observe alterations in the feeding behavior of the animals, which was probably due to the low quality of sisal, which showed a CP content of 524 $\mathrm{g} / \mathrm{kg}^{-1}$ in its chemical composition compared with the Gliricidia hay, whose average CP content was $211 \mathrm{~g} / \mathrm{kg}^{-1}$.

Table 6. Intakes ( $\mathrm{g} \mathrm{day}^{-1}$ ) of dry matter (DMI) and neutral detergent fiber (NDFI); time (min) spent feeding, ruminating, and idle; number of cuds ruminated per day $\left(\mathrm{CRD}, \mathrm{day}^{-1}\right)$; and time spent per cud ( $\left.\mathrm{s} \mathrm{cud}^{-1}\right)$ by lambs supplemented with Gliricidia fodder salt.

\begin{tabular}{|c|c|c|c|c|c|c|c|c|c|c|}
\hline \multirow{2}{*}{ Item } & \multicolumn{5}{|c|}{ Gliricidia level $\left(\mathrm{g} / \mathrm{kg}^{-1}\right)$} & \multirow{2}{*}{$\begin{array}{c}\mathrm{NaCl} \\
\text { vs. GFS }\end{array}$} & \multicolumn{3}{|c|}{ P-value } & \multirow{2}{*}{$\mathrm{CV}(\%)$} \\
\hline & 0 & 930 & 950 & 970 & 990 & & $\mathrm{~L}$ & $\mathrm{Q}$ & $\mathrm{C}$ & \\
\hline DMI & 519.0 & 721.3 & 1186.3 & 1217.6 & 940.0 & 0.050 & ns & 0.001 & ns & 11.08 \\
\hline NDFI & 431.5 & 572.3 & 892.0 & 918.3 & 741.0 & 0.001 & $\mathrm{~ns}$ & 0.002 & $\mathrm{~ns}$ & 10.88 \\
\hline Feeding (min) & 312.5 & 365.0 & 348.3 & 325.0 & 330.0 & $\mathrm{~ns}$ & $\mathrm{~ns}$ & $\mathrm{~ns}$ & $\mathrm{~ns}$ & 17.37 \\
\hline Rumination (min) & 745.0 & 661.6 & 656.6 & 633.3 & 582.5 & 0.018 & $\mathrm{~ns}$ & ns & $\mathrm{ns}$ & 9.22 \\
\hline Idleness (min) & 382.5 & 413.3 & 435.0 & 481.6 & 447.5 & ns & $\mathrm{ns}$ & ns & $\mathrm{ns}$ & 18.51 \\
\hline $\mathrm{CRD}_{\text {day }^{-1}}$ & 612.0 & 423.0 & 445.2 & 459.3 & 403.7 & 0.002 & $\mathrm{~ns}$ & ns & $\mathrm{ns}$ & 14.10 \\
\hline \multirow[t]{3}{*}{ S/cud } & 107.7 & 84.6 & 89.2 & 96.3 & 91.5 & 0.021 & ns & ns & ns & 10.52 \\
\hline & \multicolumn{9}{|c|}{ Regression equation } & $\mathrm{r}^{2}$ \\
\hline & \multicolumn{9}{|c|}{ Intake $\left(\mathrm{g} \mathrm{day}^{-1}\right)$} & \\
\hline DM & \multicolumn{9}{|c|}{$Y=-429826.78+8946.36667 x-46.4166667 x^{2}$} & 0.44 \\
\hline NDF & \multicolumn{9}{|c|}{$Y=-287890.97+5990.61667 x-31.0625000 x^{2}$} & 0.43 \\
\hline
\end{tabular}

${ }^{1} \mathrm{P}$-value for the orthogonal contrast between control and fodder salt; $\mathrm{L}=$ linear; $\mathrm{Q}=$ quadratic; $\mathrm{C}=$ cubic.

The number of cuds ruminated per day (average 432.8) as well as the time spent (s) per ruminated cud were lower $(\mathrm{P}<0.05)$ in lambs supplemented with GFS (Table 6). The decrease in number of cuds ruminated per day was offset by the larger number $(\mathrm{P}<0.05)$ of chews per ruminated cud (Table 7$)$. 
A similar response was reported by Carvalho et al. (2006), who evaluated the feeding behavior of feedlot Santa Inês sheep and observed that as the animals reduced the number of cuds ruminated per day, they increased the number of rumination chews per cud.

Table 7. Feed efficiency (DM and NDF, $\mathrm{g} \mathrm{h}^{-1}$ ), rumination efficiency (DM and NDF, $\mathrm{g} \mathrm{h}^{-1}$ ), and rumination chews (h day $^{-1}, \mathrm{n} \mathrm{cud}^{-1}$, and $\mathrm{n}$ day $^{-1}$ ) by lambs supplemented with Gliricidia fodder salt.

\begin{tabular}{|c|c|c|c|c|c|c|c|c|c|c|}
\hline \multirow{2}{*}{ Item } & \multicolumn{5}{|c|}{ Gliricidia level $\left(\mathrm{g} / \mathrm{kg}^{-1}\right)$} & \multirow{2}{*}{$\begin{array}{c}\mathrm{NaCl} \\
\text { vs. } \mathrm{GFS}^{1}\end{array}$} & \multicolumn{3}{|c|}{ P-value } & \multirow{2}{*}{$\mathrm{CV}(\%)$} \\
\hline & 0 & 930 & 950 & 970 & 990 & & $\mathrm{~L}$ & Q & $\mathrm{C}$ & \\
\hline \multicolumn{11}{|c|}{ Feed efficiency (g DM and NDF $\mathrm{h}^{-1}$ ) } \\
\hline DM & 100.0 & 119.9 & 206.8 & 225.0 & 171.0 & 0.0001 & ns & 0.0001 & ns & 16.14 \\
\hline $\mathrm{NDF}$ & 83.1 & 95.6 & 155.6 & 169.8 & 135.0 & 0.0001 & ns & 0,0001 & ns & 15.68 \\
\hline \multicolumn{11}{|c|}{ Rumination efficiency (g DM and $\mathrm{NDF}^{-1}$ ) } \\
\hline DM & 41.8 & 65.8 & 110.4 & 116.2 & 96.8 & 0.0001 & ns & 0,050 & ns & 14.33 \\
\hline $\mathrm{NDF}$ & 34.8 & 52.3 & 82.9 & 87.6 & 76.3 & 0.0001 & ns & 0,011 & ns & 13.88 \\
\hline \multicolumn{11}{|c|}{ Rumination chews } \\
\hline h/day & 17.6 & 17.1 & 16.7 & 15.9 & 16.5 & ns & ns & ns & ns & 7.17 \\
\hline $\mathrm{n} / \mathrm{cud}$ & 91.0 & 147.5 & 131.8 & 121.0 & 125.3 & 0.026 & ns & $\mathrm{ns}$ & ns & 18.04 \\
\hline $\mathrm{n} /$ day & 54.608 & 62.309 & 58.194 & 53.660 & 50.491 & ns & ns & $\mathrm{ns}$ & ns & 13.14 \\
\hline \multicolumn{10}{|c|}{ Regression equation } & $\mathrm{r}^{2}$ \\
\hline \multicolumn{11}{|c|}{ Feed efficiency (g DM and $\mathrm{NDF}^{-1}$ ) } \\
\hline DM & \multicolumn{9}{|c|}{$Y=-81699.585+1698.17833 x-8.80000000 x^{2}$} & 0.55 \\
\hline $\mathrm{NDF}$ & \multicolumn{9}{|c|}{$Y=-55047.313+1143.70650 x-5.92229167 x^{2}$} & 0.55 \\
\hline \multicolumn{11}{|c|}{ Rumination efficiency (g DM and $\mathrm{NDF}^{-1}$ ) } \\
\hline DM & \multicolumn{9}{|c|}{$Y=-37191.484+772.333500 x-3.99687500 x^{2}$} & 0.37 \\
\hline $\mathrm{NDF}$ & \multicolumn{9}{|c|}{$Y=-24407.076+506.476000 x-2.61791667 x^{2}$} & 0.36 \\
\hline
\end{tabular}

${ }^{1} \mathrm{P}$-value for the orthogonal contrast between control and fodder salt; $\mathrm{L}=$ linear; $\mathrm{Q}=$ quadratic; $\mathrm{C}=$ cubic.

Evaluating the feed and rumination efficiencies (g DM and NDF $\mathrm{h}^{-1}$ ), we observed that these variables were highest for the animals supplemented with GFS (Table 7). The better feed and rumination efficiencies occurred in response to the higher intakes of DM and NDF, of $1,016.3$ and $780.9 \mathrm{~kg}$ day $^{-1}$, respectively, by the animals fed GFS (Table 6), explaining the results obtained for the efficiencies, which are directly related to the intake expressed in $\mathrm{kg} \mathrm{day}^{-1}$. The feed and rumination efficiencies $\left(\mathrm{g} \mathrm{DM} \mathrm{h}^{-1}\right)$ found in this study agree with those reported by Almeida et al. (2011), who observed better feed and rumination efficiencies $\left(\mathrm{g} \mathrm{DM} \mathrm{h}^{-1}\right)$, in Santa Inês sheep supplemented on pasture in the dry season in response to the higher DM intake by the animals that received supplementation. However, feed and rumination efficiencies $\left(\mathrm{g} \mathrm{NDF} \mathrm{h}^{-1}\right)$ were not changed by supplementation, and according to these authors this occurred because the NDF intake was not altered between the treatments.

A quadratic effect was observed $(\mathrm{P}<0.01)$ for feed efficiency in DM and NDF, whose maximum values of $226.82 \mathrm{~g} \mathrm{DM} \mathrm{h}^{-1}$ and $170.52 \mathrm{~g} \mathrm{NDF} \mathrm{h}^{-1}$ were obtained at the levels of 964.80 and 965.50 $\mathrm{g} / \mathrm{kg}^{-1}$ of inclusion of Gliricidia in the fodder salt, respectively. Likewise, rumination efficiency in DM and NDF showed a quadratic response $(\mathrm{P}<0.05)$, with maximum estimated values of $118.85 \mathrm{~g} \mathrm{DM} \mathrm{h}^{-1}$ and $89.30 \mathrm{~g} \mathrm{NDF} \mathrm{h}^{-1}$ corresponding to the Gliricidia inclusion levels of 966.10 and $967.30 \mathrm{~g} / \mathrm{kg}^{-1}$ in the fodder salt, respectively. These responses shown by feed and rumination efficiency are probably attributed to the greater DM and NDF intakes shown by the 
lambs supplemented with fodder salt with Gliricidia levels of 950 and $970 \mathrm{~g} / \mathrm{kg}^{-1}$ compared with those containing 950 and $970 \mathrm{~g} / \mathrm{kg}^{-1}$ Gliricidia (Table 6).

Rumination chews, expressed in $\mathrm{n}$ day $^{-1}$, were not altered $(\mathrm{P}>0.05)$ by supplementation with GFS (Table 7), although there was a higher $(\mathrm{P}<0.05)$ number of chews per cud by GFS-supplemented animals than those fed $\mathrm{NaCl}$, which probably offset the lower number of cuds ruminated per day (Table 6). These results corroborate those obtained by Almeida et al. (2011), who evaluated the feeding behavior of supplemented sheep on signal grass (Urochloa mosambicensis) pastures in the dry season and did not record differences in rumination chews, expressed in $\mathrm{n} \mathrm{day}^{-1}$.
The number $\left(\mathrm{n}\right.$ day $\left.^{-1}\right)$ of feeding, rumination, and idle periods was not affected by GFS supplementation (Table 8), averaging 20.1, 25.9, and 23.6 day $^{-1}$, respectively. However, a quadratic response $(\mathrm{P}<0.01)$ was shown by number of feeding periods (meals), with maximum estimated value of $24.1 \mathrm{nday}^{-1}$ at the Gliricidia inclusion level of 958 $\mathrm{g} / \mathrm{kg}^{-1}$ in the fodder salt. The average time spent per feeding period also had a quadratic response $(\mathrm{P}<0.05)$, and the minimum estimated value was $13.3 \mathrm{~min}$ for the Gliricidia level of $957 \mathrm{~g} / \mathrm{kg}^{-1}$. Nevertheless, the increased number of meals per day with the addition of $958 \mathrm{~g} / \mathrm{kg}^{-1}$ Gliricidia was offset by the reduction in the time spent per meal (Table 8).

Table 8. Number of periods $\left(\mathrm{n} \mathrm{day}^{-1}\right)$ and time spent per feeding, rumination, and idle period; intakes of DM and NDF per meal (g); and DM and NDF intake $\left(\mathrm{min} \mathrm{kg}^{-1}\right)$ by lambs supplemented with Gliricidia fodder salt.

\begin{tabular}{|c|c|c|c|c|c|c|c|c|c|c|}
\hline \multirow{2}{*}{ Item } & \multicolumn{5}{|c|}{ Gliricidia level $\left(\mathrm{g} / \mathrm{kg}^{-1}\right)$} & \multirow{2}{*}{$\begin{array}{c}\mathrm{NaCl} \\
\text { vs. } \mathrm{GFS}^{1}\end{array}$} & \multicolumn{3}{|c|}{ P-value } & \multirow{2}{*}{$\mathrm{CV}(\%)$} \\
\hline & 0 & 930 & 950 & 970 & 990 & & $\mathrm{~L}$ & Q & $\mathrm{C}$ & \\
\hline \multicolumn{11}{|c|}{ Number of periods $\left(\mathrm{n}\right.$ day $\left.^{-1}\right)$} \\
\hline Meal & 17.0 & 19.0 & 23.6 & 23.3 & 18.0 & ns & ns & 0.001 & ns & 9.30 \\
\hline Rumination & 23.5 & 23.0 & 29.0 & 26.0 & 28.0 & ns & ns & ns & ns & 14.97 \\
\hline Idleness & 21.0 & 23.6 & 24.3 & 24.3 & 25.0 & ns & ns & ns & ns & 17.31 \\
\hline \multicolumn{11}{|c|}{ Time spent per period $(\mathrm{min})$} \\
\hline Meal & 18.5 & 19.3 & 14.7 & 13.9 & 23.0 & ns & ns & 0.004 & ns & 18.11 \\
\hline Rumination & 32.0 & 28.9 & 23.1 & 24.3 & 22.1 & ns & ns & ns & ns & 18.30 \\
\hline Idleness & 17.9 & 17.9 & 17.8 & 19.8 & 18.1 & ns & ns & ns & ns & 19.61 \\
\hline \multicolumn{11}{|c|}{ DM and NDF intake per meal (g) } \\
\hline $\mathrm{DM}$ & 31.0 & 38.2 & 50.6 & 52.3 & 52.3 & 0.001 & 0.022 & ns & ns & 14.17 \\
\hline NDF & 25.7 & 30.2 & 38.0 & 39.5 & 41.4 & 0.006 & 0.025 & ns & ns & 14.75 \\
\hline \multicolumn{11}{|c|}{ DM and NDF intake $\left(\min \mathrm{kg}^{-1}\right)$} \\
\hline $\mathrm{DM}$ & 600.5 & 506.4 & 297.2 & 266.9 & 351.1 & 0.0001 & ns & 0.001 & ns & 10.45 \\
\hline NDF & 722.3 & 640.4 & 395.0 & 354.3 & 447.7 & 0.0001 & ns & 0.001 & ns & 12.75 \\
\hline \multicolumn{10}{|c|}{ Regression equation } & $\mathrm{r}^{2}$ \\
\hline \multicolumn{11}{|c|}{ Number of periods $\left(\mathrm{n}\right.$ day $^{-1}$ ) } \\
\hline Feeding & \multicolumn{9}{|c|}{$Y=-5719.8750+119.833333 x+0.62500000 x^{2}$} & 0.66 \\
\hline \multicolumn{11}{|c|}{ Time spent per period (min) } \\
\hline Feeding & \multicolumn{9}{|c|}{$Y=7906.91746-164.963500 x+0.86187500 x^{2}$} & 0.95 \\
\hline \multicolumn{11}{|c|}{$\mathrm{DM}$ and NDF intake per meal (g) } \\
\hline $\mathrm{DM}$ & \multicolumn{9}{|c|}{$Y=-164.23817+2.21483333 x$} & 0.25 \\
\hline NDF & \multicolumn{9}{|c|}{$Y=-130.16800+1.74466667 x$} & 0.34 \\
\hline \multicolumn{11}{|c|}{ DM and NDF intake $\left(\min \mathrm{kg}^{-1}\right)$} \\
\hline $\mathrm{DM}$ & \multirow{2}{*}{\multicolumn{9}{|c|}{$\begin{array}{l}Y=171691.018-3546.58100 x+18.3425000 x^{2} \\
Y=198449093-409605567 x+21172500 x^{2}\end{array}$}} & 0.41 \\
\hline $\mathrm{NDF}$ & & & & & & & & & & 0.46 \\
\hline
\end{tabular}

${ }^{1} \mathrm{P}$-value for the orthogonal contrast between control and fodder salt; $\mathrm{L}=$ linear; $\mathrm{Q}=$ quadratic; $\mathrm{C}=$ cubic. 
An increase was observed $(\mathrm{P}<0.01)$ in the intakes of DM and NDF, expressed in $\mathrm{g} \mathrm{meal}^{-1}$, and a decrease $(\mathrm{P}<0.01)$ in the time spent on consumption of DM and NDF, expressed in min $\mathrm{kg}^{-1}$, by the animals supplemented with GFS compared with those which received $\mathrm{NaCl}$ (Table 8). These responses can be attributed to the greater DM and NDF intakes shown by the GFS-supplemented lambs (Table 6). The intakes of DM and NDF, expressed in $\mathrm{g} \mathrm{meal}^{-1}$, increased linearly $(\mathrm{P}<0.05)$, with every $10 \mathrm{~g} / \mathrm{kg}^{-1}$ inclusion of Gliricidia in the fodder salt providing an increase of 2.21 and 1.74 $\mathrm{g}$, in the intakes of DM and NDF, respectively. However, when expressed in min $\mathrm{kg}^{-1}, \mathrm{DM}$ and NDF intakes displayed a quadratic effect $(\mathrm{P}<0.01)$, with minimum values estimated at 255.3 and 342.0 , $\min \mathrm{kg}^{-1}$ for the Gliricidia levels of 966.70 and $967.3 \mathrm{~g} / \mathrm{kg}^{-1}$, respectively. This possibly occurred in response to the better feed efficiency (g DM and $\mathrm{NDF} / \mathrm{h}$ ) of the animals supplemented with fodder salt containing Gliricidia at the levels of 950 and $970 \mathrm{~g} / \mathrm{kg}^{-1}$ (Table 7).

Lambs receiving GFS showed an increase $(\mathrm{P}<0.01)$ in rumination activity, expressed in $\mathrm{g}$ DM and NDF cud when compared with those supplemented with $\mathrm{NaCl}$. A quadratic effect was also observed $(\mathrm{P}<0.05)$, with maximum values of 2.8 and $2.1 \mathrm{~g}$ cud DM and NDF for the Gliricidia inclusion levels of 965 and $966 \mathrm{~g} / \mathrm{kg}^{-1}$, respectively. This result may be a reflection of the high DM and NDF intakes by the animals that consumed GFS (Table 6). There was a decrease $(\mathrm{P}<0.01)$ in rumination activity by the animals that received GFS in relation to those fed $\mathrm{NaCl}$, expressed in min $\mathrm{kg}^{-1} \mathrm{DM}$ and NDF (Table 9), and a quadratic response $(\mathrm{P}<0.01)$, with minimum values of 493.8 and $659.6 \mathrm{~min} \mathrm{~kg}^{-1} \mathrm{DM}$ and NDF for the levels of 968.50 and $969.00 \mathrm{~g} / \mathrm{kg}^{-1}$, respectively. The higher rumination efficiency by the animals fed GFS likely led to a lower rumination time in $\min \mathrm{kg}^{-1}$ DM and NDF.

Table 9. Rumination (g DM and NDF cud ${ }^{-1}$ ), rumination ( $\mathrm{min} \mathrm{kg}^{-1} \mathrm{DM}$ and NDF), and total chewing (min $\mathrm{kg}^{-1} \mathrm{DM}$ and NDF) of lambs supplemented with Gliricidia fodder salt.

\begin{tabular}{|c|c|c|c|c|c|c|c|c|c|c|}
\hline \multirow{2}{*}{ Item } & \multicolumn{5}{|c|}{ Gliricidia level $\left(\mathrm{g} / \mathrm{kg}^{-1}\right)$} & \multirow{2}{*}{$\begin{array}{c}\mathrm{NaCl} \\
\text { vs. } \mathrm{GFS}^{1} \\
\end{array}$} & \multicolumn{3}{|c|}{ P-value } & \multirow{2}{*}{$\mathrm{CV}(\%)$} \\
\hline & 0 & 930 & 950 & 970 & 990 & & $\mathrm{~L}$ & Q & $\mathrm{C}$ & \\
\hline \multicolumn{11}{|c|}{ Rumination (g DM and NDF cud ${ }^{-1}$ ) } \\
\hline $\mathrm{DM}$ & 0.86 & 1.7 & 2.7 & 2.7 & 2.3 & 0.0001 & ns & 0.030 & ns & 23.39 \\
\hline NDF & 0.71 & 1.3 & 2.0 & 2.0 & 1.8 & 0.0001 & ns & 0.050 & ns & 22.91 \\
\hline \multicolumn{11}{|c|}{ Rumination (min $\mathrm{kg}^{-1} \mathrm{DM}$ and NDF) } \\
\hline $\mathrm{DM}$ & 1433.2 & 933.7 & 567.8 & 520.0 & 933.7 & 0.0001 & ns & 0.002 & ns & 12.55 \\
\hline $\mathrm{NDF}$ & 1724.0 & 1176.8 & 753.6 & 689.3 & 789.0 & 0.0001 & ns & 0.007 & ns & 13.15 \\
\hline \multicolumn{11}{|c|}{ Total chewing (min $\mathrm{kg}^{-1} \mathrm{DM}$ and NDF) } \\
\hline $\mathrm{DM}$ & 2033.7 & 1440.2 & 865.0 & 787.0 & 1055.5 & 0.0001 & ns & 0.0001 & ns & 10.33 \\
\hline NDF & 2446.3 & 1817.2 & 1148.6 & 1043.6 & 1338.7 & 0.0001 & ns & 0.0001 & ns & 10.94 \\
\hline \multicolumn{10}{|c|}{ Regression equation } & $\mathrm{r}^{2}$ \\
\hline \multicolumn{11}{|c|}{ Rumination (g DM and NDF cud ${ }^{-1}$ ) } \\
\hline $\mathrm{DM}$ & \multicolumn{9}{|c|}{$Y=-819.90167+17.0500000 x-0.08833333 x^{2}$} & 0.26 \\
\hline NDF & \multicolumn{9}{|c|}{$Y=-538.33175+11.1896667 x-0.05791667 x^{2}$} & 0.23 \\
\hline \multicolumn{11}{|c|}{ Rumination (min $\mathrm{kg}^{-1} \mathrm{DM}$ and NDF) } \\
\hline $\mathrm{DM}$ & \multicolumn{9}{|c|}{$Y=273382.692-5635.25300 x+29.0925000 x^{2}$} & 0.17 \\
\hline NDF & \multicolumn{9}{|c|}{$\mathrm{Y}=307773-6336.21717 \mathrm{x}+32.6814583 \mathrm{x}^{2}$} & 0.19 \\
\hline \multicolumn{11}{|c|}{ Total chewing (min $\mathrm{kg}^{-1} \mathrm{DM}$ and NDF $)$} \\
\hline $\mathrm{DM}$ & \multicolumn{9}{|c|}{$Y=492664.074-10186.1222 x+52.7318750 x^{2}$} & 0.24 \\
\hline NDF & \multicolumn{9}{|c|}{$Y=563458.242-11640.1055 x+60.2243750 x^{2}$} & 0.26 \\
\hline
\end{tabular}

${ }^{1} \mathrm{P}$-value for the orthogonal contrast between control and fodder salt; $\mathrm{L}=$ linear; $\mathrm{Q}=$ quadratic; $\mathrm{C}=$ cubic. 
In the same way, total chewing, expressed in min $\mathrm{kg}^{-1} \mathrm{DM}$ and NDF, was influenced $(\mathrm{P}<0.01)$ by supplementation with GFS, with a quadratic effect observed $(\mathrm{P}<0.01)$ as a function of Gliricidia inclusion levels. Estimated minimum values were 755.3 and 1,011.3 for the levels of 965.80 and $966.30 \mathrm{~g} / \mathrm{kg}^{-1}$, respectively. The lower values for total chewing time, in min $\mathrm{kg}^{-1} \mathrm{DM}$ and NDF, for the animals supplemented with GFS, may be explained by the greater feed and rumination efficiency observed with that diet (Table 8).

\section{Conclusion}

Supplementing lambs with Gliricidia fodder salt increases nutrient intake and improves the feed and rumination efficiency of these animals. Inclusion of up to $97 \%$ Gliricidia hay is recommended in the preparation of fodder salt for lambs, because the mineral-salt intake will be within the recommended range for sheep.

\section{References}

ALMEIDA, P. J. P.; PEREIRA, M. L. A.; AZEVEDO, S. T.; ALVES, E. M.; SOUZA, D. R.; SANTOS, A. B.; PEREIRA, T. C. J.; PEDREIRA, M. S. Fontes energéticas suplementares para ovinos Santa Inês em pastagens de capim urocloa na época seca. Revista Brasileira de Saúde e Produção Animal, Salvador, v. 12, n. 1, p. 140-154, 2011.

ARAÚJO FILHO, J. A.; ALVES, J. U.; BRAGA JUNIOR, W. G. Trabalhador na ovinocultura. Brasília: SEBRAE /SUDENE/SENAR, 2000. 88 p.

BARBOSA, J. C.; MALDONADO JÚNIOR, W. AgroEstat - Sistema para análises estatísticas de ensaios agronômicos. Versão 1.1.0.668. Jaboticabal: Departamento de ciências Exatas, 2013.

BÜRGER, P. J.; PEREIRA, J. C.; QUEIROZ, A. C.; SILVA, J. F. C.; VALADARES FILHO, S. C.; CECON, P. R.; CASALI, A. D. P. Comportamento ingestivo em bezerros holandeses alimentados com dietas contendo diferentes níveis de concentrado. Revista Brasileira de Zootecnia, Viçosa, MG, v. 29, n. 1, p. 236-242, 2000.

CARVALHO FILHO, O. M.; DRUMOND, M. A.; LANGUIDEY, P. H. Gliricidia sepium: leguminosa promissora para regiões semi-áridas. Petrolina: EMBRAPA-CPATSA, 1997. 16 p. (Circular técnica, 35).

CARVALHO, G. G. P.; PIRES, A. J. V.; SILVA, R. R.; RIBEIRO, L. S. O.; CHAGAS, D. M. T. Comportamento ingestivo de ovinos Santa Inês alimentados com dietas contendo farelo de cacau. Revista Brasileira de Zootecnia, Viçosa, MG, v. 37, n. 4, p. 660-665, 2006.

CAVALCANTE, A. C. R.; PEREIRA, O. G.; VALADARES FILHO, S. C. V.; RIBEIRO, K. G.; GARCIA, R.; LANA, R. P. L. Dietas contendo silagem de milho (Zea maiz L.) e feno de capim-Tifton 85 (Cynodon spp.) em diferentes proporções para bovinos. Revista Brasileira de Zootecnia, Viçosa, MG, v. 33, n. 6, p. 2394-2402, 2004.

CIRNE, L. G. A.; BARONI, M. R.; OLIVEIRA, P. A.; OLIVEIRA, G. J. C.; JAEGER, S. M. P. L.; BAGALDO, A. R. Performance of lambs supplemented with fodder salt Gliricidia sepium (Jacq.). Revista Brasileira de Zootecnia, Viçosa, MG, v. 41, n. 4, p. 959-962, 2012.

COSTA, M. R. G. F.; CARNEIRO, M. S. S.; PEREIRA, E. S.; MAGALHÃES, J. A.; COSTA, N. L.; MORAIS NETO, L. B.; MOCHEL FILHO, W. J. E.; BEZERRA, A. P. A. Utilização do feno de forrageiras lenhosas nativas do Nordeste brasileiro na alimentação de ovinos e caprinos. PUBVET, Londrina, v. 5, n. 7, p. 1034-1041, 2011.

GONÇALVES, G. S.; OLIVEIRA, G. J. C.; JAEGER, S. M. P. L.; OLIVEIRA, R. L.; CAMPOS, J. O.; REZENDE, L. S. Desempenho de cordeiros alimentados com dietas contendo sal forrageiro de espécies vegetais xerófitas. Revista Brasileira de Zootecnia, Viçosa, MG, v. 37, n. 12, p. 2185-2190, 2008.

HODGSON, J. Grazing management: science into practice. Harlow: Longman Handbooks in Agriculture, 1990. $203 \mathrm{p}$.

MORENO, G. M. B.; SILVA SOBRINHO, A. G. S.; LEÃO, A. G.; LOUREIRO, C. M. B.; PEREZ, H. L.; ROSSI, R. C. Desempenho, digestibilidade e balanço de nitrogênio em cordeiros alimentados com silagem de milho ou cana-de-açúcar e dois níveis de concentrado. Revista Brasileira de Zootecnia, Viçosa, MG, v. 39, n. 4, p. 853-860, 2010.

NUNES, H. F. P.; BAGALDO, A. R.; OLIVEIRA, R. L.; OLIVEIRA, G. J. C.; CAMPOS, B. M.; SOUZA, R. M. B. N. Comportamento ingestivo em ovinos mestiços da raça Santa Inês, alimentados com sal forrageiro de resíduo desidratado de sisal (Agave sisalana). In: CONGRESSO BRASILEIRO DE ZOOTECNIA, 47., 2010, Salvador. Anais... Salvador: Associação Brasileira de Zootecnia, 2010. 1 CD-ROM. 
OLIVEIRA, G. J. C.; JAEGER, S. M. P. L.; BAGALDO, A. R.; OLIVEIRA, P. A. Fodder salt fed to small ruminants. Revista Brasileira de Zootecnia, Viçosa, MG, v. 39, p. 364-368, 2010. Suplemento Especial.

POLLI, V. A.; RESTLE, J.; SENNA, D. B.; ALMEIDA, S. R. S. Aspectos relativos à ruminação de bovinos e bubalinos em regime de confinamento. Revista Brasileira de Zootecnia, Viçosa, MG, v. 25, n. 5, p. $987-$ 993, 1996.

S'THIAGO, L. R. L. Suplementação de bovinos em pastejo. In: ENCONTRO DE TECNOLOGIAS PARA A PECUÁRIA DE CORTE, 11., 1999, Campo Grande. Anais... Campo Grande: Palácio Popular da Cultura, 1999. 1 CD-ROM.
STRADA, E. S. O.; OLIVEIRA, G. J. C.; JAEGER, S. M. P. L.; SILVA, A. M.; ALMEIDA, A. M.; LOPES, N. C. M.; SANTOS, R. A. Efeito da suplementação com sal forrageiro de leucena (Leucaena leucocephala (Lam) de Wit) sobre desempenho e características de carcaça de ovinos deslanados em regime de pasto. Magistra, v.18, n. 2, p.1-7, 2006.

SILVA, A. M.; OLIVEIRA, G. J. C.; JAEGER, S. M. P. L.; ALMEIDA, A. M. M.; OLIVEIRA, S. E. S. Consumo de sal forrageiro por ovinos deslanados em confinamento. Magistra, Cruz das Almas, v. 18, n. 1, p. 1-6, 2006.

SILVA, D. J.; QUEIROZ, A. C. Análise de alimentos: métodos químicos e biológicos. 3. ed. Viçosa, MG: UFV, 2002. 235 p.

VAN SOEST, P. J. Nutritional ecology of the ruminant. New York: Cornell University Press, 1994. 476 p. 